\title{
家蚛絹フィブロインの分子形態
}

$\begin{array}{lllll}\text { 農林水産省要系試験場 } & \text { 塚 } & \text { 田 } & \text { 益裕 } \\ \text { 東京農工大学工学部 } & \text { 平 } & \text { 林 } & \text { 潔 }\end{array}$

\section{MOLECULAR CONFORMATION OF Bombyx mori SILK FIBROIN}

\author{
By Masuhiro Tsukada and Kiyoshi Hirabayashi ${ }^{* 1}$ \\ (Sericultural Experiment Station, Yatabe, Tsukuba, Ibaraki, Japan) \\ *1 (Tokyo University of Agriculture and Technology, Koganei, Tokyo, Japan)
}

The molecular conformation of silk fibroin was investigated by infrared spectroscopy (IR) and circular dichroism method (CD). The silk fibroin in the liquid phase was found to have random coil structure containing a small amount of $\alpha$ helix. The $\alpha$ helix content of silk fibroin, dispersed in pure water, increased with increasing the periods during fifth instar of silkworm larvae. This fact was related to the increase of the water content in liquid silk fibroin. Silk fibroin hydrolyzed by aqueous $\mathrm{HCl}$ solution showed the strong IR absorption band assigned to $\beta$ structure as well as the weak band at $620 \mathrm{~cm}^{-1}$ (amide V) attributing to $\alpha$ helix. The results of IR and CD suggest that the peptide chains consisting of $\alpha$ helix do not exceed several units, taking into account the $x$-ray diffraction pattern exhibiting no $\alpha$-helical chains.

(Received February 15, 1982)

\section{1. 緒言}

飯塚 ${ }^{1)}$ ，平林ら ${ }^{2)}$ 执よざ片网 ${ }^{3)}$ は䅌禾腺内液状絹を用 いて, 絹系が形成される際の機械的变性機構あるいは絹 フィプロイン中に見出される $\beta$ 核発生のメカ二ズムを明

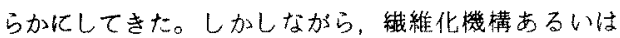
SilkIの構造解析など未解決の問題加㳖然しして残され ている。とれら未解決の問題を検討する上で絹フィブロ インの分子形態索詳細に究明するととは極めて重要であ ろうと考える。

本研究では溶液中および固体状態におうりる絹フィブロ インの分子形態を分光分析測定により険討し，絹フィブ ロインにはーヘリックスの形態をとるものが含まれると とを明らかにする。

\section{2. 試料および寒験方法}

\section{1 試 料}

再生程フィブロイン溶液；絹系老臭化りチウム飽和溶 液中で溶解させた後、十分透析を扢てない $\mathrm{Li}^{+}$を完全に 除去して作成した。水溶液濃度 $(0.03 \mathrm{~mol} / l)$ は平均厂ミ 八酸残基の分子量 (88.9)を基にして算出したものである。

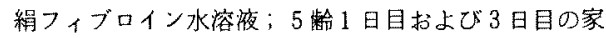

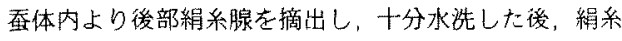
腺内の液状絹フィブロインを蒸留水に希粎分散させた。 絹フィブロイン水溶液を調製した直後にCD测定をおこ なった。

扣水你解观理試料; 絹糸の扣水分解狆理は $0.6 \mathrm{~N}$ 垛酸 水溶液を用い $98 \mathrm{C}$ で 5 時間扔こなった。がラスフィルタ - (3G) に上り処理溶液を沪過し，加水分解残留物老十 分洗浄した徭， $105^{\circ} \mathrm{C}$ で 2 時間乾燥させた。 


\section{2 実験方法}

円偏光二色性; 日本分光社製 J-20 型自揢族光分散計 在用い，0.1 mm石英セル中で测定した。

赤外吸取スペクトル；日本分光社製 IR-G型回折格子 型分光光度計を用い，波数 $1800-400 \mathrm{~cm}^{-1}$ ○籍围で测 定した。

\section{3、実験結果}

3.1 溶液中における絹フィブロインの分子形態 䋩系フィブロインを臭化リチウム水溶中で溶解して得 た再生絹フィプロインの分子形態を明ら加するため， 円偏光二色性 (CD) 測定を扔こなった。再生絹フィブロ イン水溶液のCDZペクトル(四1)には $198 \mathrm{~nm}$ に負のピ ークが钼察される。これがランダムコイル構造を有する ポリーLーリジンに特徽的な CD曲線 ${ }^{7)}$ 上類似しているこ と加方，再生絹フィプロインの主要な分子形態はランダ ムコイル ム水溶波に絹フィブロインを溶解させることなく，家查 の絹采腺内容物を直接蒸留水浠䣋分散させたいわゆる 未変性絹フィブロインの分子形熊の特徴を検討するため， 5 路 1 日目(図 2(a)) 执よび3日目（図2(b)) の後部絹 系腺内より取り出した末変性状態に扣りる絹フィブロイ

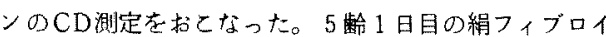

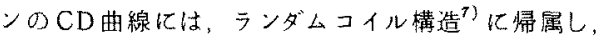
$200 \mathrm{~nm}$ に谷を有するブロードな吸収が観察される。ま た 5 齢 3 日目で得られた試料のCD曲線の $208 \mathrm{~nm}$ 招よ び222 nm近辺には $\alpha$ ーヘリックスに㷌属する負のバン ドが観察された。図2の結果により，絹フィブロイン のみーヘリッタス含量は熟查の経過日数につれて增加 するなどれーへリ，クス量の差在確認するととができ た。

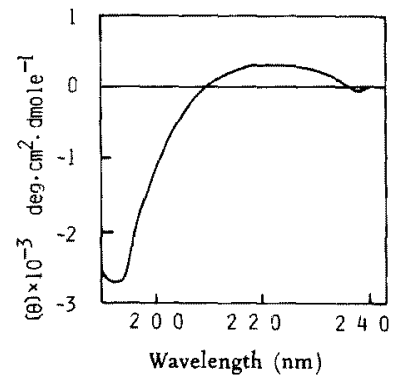

Fig. 1. Circular dichroism (CD) spectra of regenerated silk fibroin in aqueous solution.

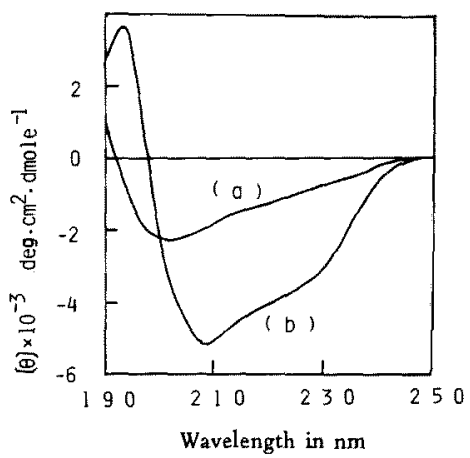

Fig. 2. CD spectra of native silk fibroin in aqueous solution. Spectra were recorded immediately after dissolving the liquid silk fibroin in pure water.

(a) silk fibroin specimen for the first day of 5 th instar silkworm larvae.

(b) specimen for the 3rd day of 5 th instar silkworm larvae.

\section{2 固体状態における絹フィブロインの分子形 態}

水溶液中における未変性絹フィブロインに $\alpha$-ヘリッ クスの形態をとるものが含まれることを明らかにしたが，

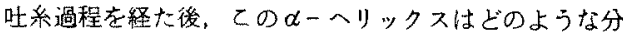
子形態変化を受けるのかを检討するため，絹フィブロイ ン䋐維および加水分解処理試料赤外吸収スペクト儿測 定在扔てなった（図 3)。加水分解処理前の赤外吸収スペ クトル(図3(a))にはアミドI バンドが $1630 \mathrm{~cm}^{-1}$ に, アミドIIバンドが $1530 \mathrm{~cm}^{-1}$ に，アミドVバンドが 700 $\mathrm{cm}^{-1}$ に観察される。乙れらのバンドはいずれも $\beta$ 構造 特有 ${ }^{B)}$ のバンドであるととが知られている。加水分解処 理した絹フィブロイン試料の赤外吸収スペクトルを図 3 （b）に示士。加水分解処理試料（b）の赤外吸収スペク卜 ルにはアミドバンドが $1695 \mathrm{~cm}^{-1}, 1630 \mathrm{~cm}^{-1} \mathrm{~K}, ア$ ミドIバンドが $1525 \mathrm{~cm}^{-1}$ K，およびアミドVバンドが $700 \mathrm{~cm}^{-1}$ に観察される ${ }^{8)}$ ため試料の分子形態の大勢は 逆平行 $\beta$ 構造であるととが示唆された。 $\alpha$-ヘリックス に㷌属する樶收 ${ }^{8)}$ がアミドVバンドの $620 \mathrm{~cm}^{-1}$ に見出 されるととから，絹フィブロインには 分子形態をとるあのが含まれるすのと考えられる。それ 中え未変性䅌フィブロイン水容液中で観察された $\alpha$ 一 リックスは絹系が形成された後の織維状試料の中でも依 然として見出されるととが明らかとなった。 


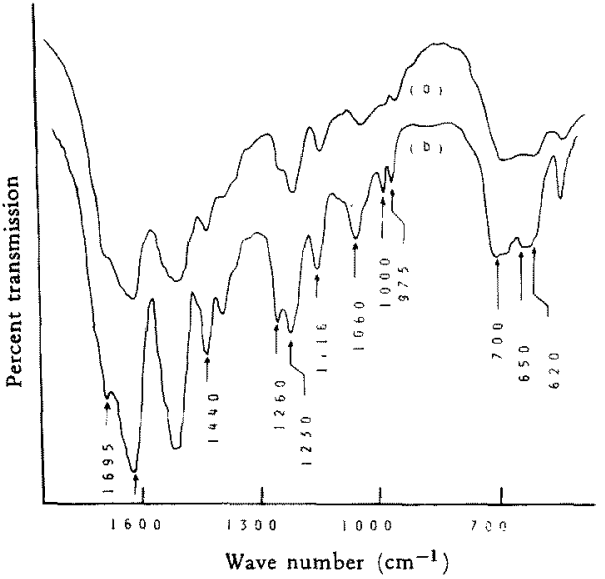

Fig. 3. Infrared spectra of silk fibroin.

(a) degummed silk fibroin thread.

(b) specimen obtained by hydrolyzing the degummed silk fibroin in the $\mathrm{HCl}$ solution.

\section{4. 考察}

續フィブロインの分子形態には $\alpha$ にリックスをとる bのが含まれずランダムコイル構造を主体上した構造で あると考えられてきたが ，朱变性絹フィブロインの 水溶液には $\alpha$ ーリックスが存在するとよおよび $\alpha$ 一 リックスの含有率は熟菳の経過日数につれて次第に增加 するこよなどを本実験で確めることができた。なおこの

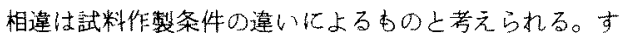
なわち，臭化りチウム水溶液処理により得られだ，絹つ ィブロイン試料を用いた従来の万法いに対して，本契験 では未変性絹フィブロインを用いているのが特徴的であ る。臭化リチウム処理により試料中の 水素結合が溶媒の作用で切断されるととにより，ランダ ムコイル構造を呈するように変化したものと考えればこ の相違を矛盾なく説明できる。蛋白質におよぼす臭化り チウムの作用は hydrophobicなアミ，酸残基の相互作用 を弱わるすのではないか，分子のへリックス構造を破壊 するあのであるとする浜口゙の考察は上記の推定の妿当 性を示唆するおのであるう。

著者ら ${ }^{10)}$ は家查綟系腺内の液状絹在蒸留水中に浸漬し た際，分散時間が経過し絹フィプロインの溶出がはじ まる上，水溶液中では るととを明らかにした。絹フィブロインに スの形態をとるものが含まれるとする本害験の結果は前 報 ${ }^{10)}$ の実験事実上符合する屯の上考元られる。 $\alpha$-へリ ックスの合有率の変化比関連して，片岡 ${ }^{11}$ は，家寔䇶つ

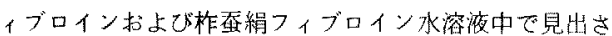
れるへリ力ルな構造"1 は濃度依存性のあるととを旋光 分散 (ORD) 扰上び円偏光二色性 (CD) 澌定の結果上り 明ら加ししているすおわち，柞至緍つィブロインでは

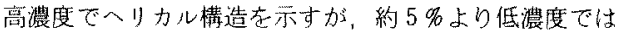

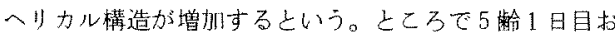
よひ3日目の末変性䋧フィブロイン水溶液のCD曲線に 差が見られたが，乙れは絹系腺に含まれる水分率の微孥 な変化により綃つィブロイン濃度依存性にもよづいて ヘリックス加観察されたあのと考艺られよう。䅌系腺内 の水分率の測定に上れば 5 齢1 日目での水争率は $93.8 \%$

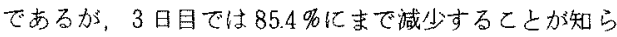
れている ${ }^{12)}$ 。絹系腺内の水分率の減少すなわ占絹フィブ ロイン濃度の增加により，5䕆 3 日目の試料にみ一へリ ックの增加加钼察されたものと考完られる。

メーヘリックスは上記で述べたとおり絹つィブロイン

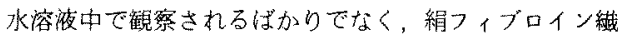
維中でも存在するととが加水分解処理試料の赤外吸収又 ペクトルの測定結果から示睃された。絹フィブロイン瀻 維(図 3(a)) の赤外吸収スペクトルにはアミドVバンド が極めて覆の広い服收しなって現われているため，620 $\mathrm{cm}^{-1}$ の吸収の有無は必明らかでなかった。しか し，㧈水分解処理により，韭結晶領域におりるランダム コイル部分を構成する分子鎖が除去されるにつれて ${ }^{15}$ ， 絹フィブロインに本来存在していた 有量が相対的に増加するため，試料の赤外吸收スぺクト 儿(図3(b))に胃られたと扣り $620 \mathrm{~cm}^{-1}$ 近辺に殹取加 現われたもの上推定される。著者ら ${ }^{16)}$ (赫外領域に打 る絹フィブロイン繊維の多重反射(ATR)スペクトルの 湘定により，ATRスペクトルにはアドVバンドが 620 $\mathrm{cm}^{-1}$ に極めて明瞭に観察されるととを報告した。 ATR スペクトルについて测定上の特徽は，解析する上で比較 的良好な分解能が得られるとと，およじ測定試料は $\mathrm{KBr}$ 錠剂法によらず䋐維状のまま用いるため試料の内部構造

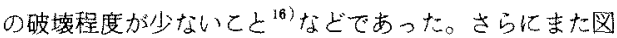
3の結果加ら古明占かなよう㧈水分解观理試料の亦外 吸収スペクトルの測定に上り 認さ机たか，との試料のX線回折写真には $\alpha$ 一リック スにもしつくく回折は見出されなかった。てれは家虫絹つ

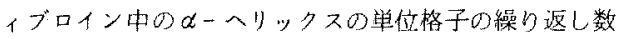
が少なく，かつれーヘリックスは極在しないで存在する ためであるう。結晶を棈成する慗位格子が9個以下だと， この構造笚位にあとづく回折は見引れず単なるハローパ ターンになってしまうことがX線結晶国折理䜽 ${ }^{13,14}$ に上

*1家虫絹フィブロインのーリカル構造は スであると断定はしていない 
り明らかにされている。したがっで家冓絹フィブロイン の加水分解炠理試料のX線回折写真に $\alpha$-ヘリックスに もとつく回折が観察されないよいう従来の実験結果は試 料中の か数個程度であるためによるものと考える。

\section{5. 結論}

签液状態および固体状態における絹フィブロインの分 子形態を検討した結果，以下の知見が得られた。

1. 水溶液中における再生絹フィブロインおよび末変 性絹フィブロインの分子形態は異なる。再生絹フィブロ インの主要な分子形態はランダムコイルであるのに反し， 未変性絹フィブロインには $\alpha$ ヘリックスの形態をとる あのが含まれ，その含有率は 5 蛒の経過日数につれて增 抑する。

2. 加水分解好理試料の赤外吸収スペクトルには逆平 行 $\beta$ 構造に慢属する吸収の他に， $\alpha$-ヘリックスに特有 な $620 \mathrm{~cm}^{-1}$ (アミドV)の吸収が見出される。

3.X線回折写真には $\alpha$ ーリックスにもとつく回折 が全く見出されないととから， 分子銷の繰り返し単位は数個程度であろうと推定される。

\section{文献}

1) E. lizuka; Biorheology, 3, 141 (1966)

2）平林 潔，石川 博，笠井暢民，角户正夫，工化，
73, 1381(1970)

3) 片岡紛三, 緎学誌, 34,80(1978)

4) 飯塚英策，生化学，39，1(1967)

5）馬越 淳，笠井暢民，角户正夫，高分子論文集， 30, 649 (1973)

6) 片岡紘三，植松市太郎，高分子論文集， $33 ， 453$ (1976)

7) N. Greenfield, G. D. Fasman; Biochemistry, 8, 4108 (1969)

8) T. Miyazawa, E. R. Blout; J. Am. Chem. Soc., 83, 712 (1961)

9）浜口浩三，生体高分子I，生物物理学講座 4, 日本 生物物理学会編，吉缃書店，京都，p.183(1965)

10) M. Tsukada, T. Komoto, T. Kawai; Polym. $J$, 6, 503 (1979)

11）片岡紘三，“昆虫学最近の進告”，石井象二郎編， 東京大学出版社, 東京, p. 516 (1981)

12）荻原清治，“萑藏学”，島田書籍 KK, 上田市, p. 61 (1951)

13）桐山良一, “X線結晶学”, 上卷, 上田 勇編, 丸善，東京，p.729 (1959)

14）角户正夫，笠护蝪民，“高分子X線回折”，丸善， 東京, p. 37 (1968)

15）石川博，祖父近寞，松崎辟、信大䄉研報， 10, 176(1960)

16）塚田益裕，石黑善夫，平林潔，瀻学誌， 36 , 314 (1980) 